\title{
Abnormal Expression of CD54 in Mixed Reactions of Mononuclear Cells from Hyper-IgE Syndrome Patients
}

\author{
Adriano M Martínez, Carlos J Montoya, María T Rugeles, José L Franco, Pablo J Patiño+
}

Grupo de Inmunodeficiencias Primarias, Grupo de Inmunovirología, Facultad de Medicina, Corporación Biogénesis, Universidad de Antioquia, Carrera 51D \# 62-29, Medellín, Colombia

\begin{abstract}
Hyper-IgE syndrome (HIES) is a rare multisystem disorder characterized by increased susceptibility to infections associated with heterogeneous immunologic and non-immunologic abnormalities. Most patients consistently exhibit defective antigen-induced-T cell activation, that could be partly due to altered costimulation involving accessory molecules; however, the expression of these molecules has never been documented in HIES. Therefore, we investigated the expression of CD11a, CD28, CD40, CD54, CD80, CD86, and CD154 in peripheral blood mononuclear cells from six patients and six healthy controls by flow cytometry after autologous and mixed allogeneic reactions. Only the allogeneic stimuli induced significant proliferative responses and interleukin 2 and interferon gamma production in both groups. Most accessory molecules showed similar expression between patients and controls with the exception of CD54, being expressed at lower levels in HIES patients regardless of the type of stimulus used. Decreased expression of CD54 could partly explain the deficient $T$ cell activation to specific recall antigens in HIES patients, and might be responsible for their higher susceptibility to infections with defined types of microorganisms.
\end{abstract}

Key words: hyper-IgE syndrome - allogeneic mixed reactions - accessory molecules - CD54

Hyper-IgE syndrome (HIES) (OMIM\#147060) is a rare disorder of unknown etiology with immunologic abnormalities characterized by recurrent skin infections and chronic dermatitis, mucocutaneous candidiasis, cyst-forming lung infections, eosinophilia, and high levels of serum IgE (Buckley 2001). Its multisystem nature is now recognized because of the presence of non-immunologic abnormalities of the face, dentition, bones, and connective tissue (Grimbacher et al. 1999a). Most cases are sporadic but HIES can be inherited in its classic form as an autosomal dominant trait with variable expressivity. An autosomal recessive variant with severe recurrent fungal and viral infections as well as vascular events, absence of skeletal or dental abnormalities and development of pneumatoceles was recently described (Renner et al. 2002). Proximal chromosome 4q has been defined as a candidate region for disease genes for HIES (Grimbacher et al. 1999b).

Classic studies of immune function have not identified consistent immunologic defects in all patients making it difficult to identify disease genes in HIES. Thus, a systematic assessment of infections and clinical features, standard laboratory tests, and the HIES-NIH scoring system remain the only current approaches to making a diagnosis (Grimbacher et al. 2002). HIES patients exhibit nor-

Financial support: Committee for the Development of the Investigation of the University of Antioquia and Colombian Institute for the Advancement of Science and Technology grant 1115-04-405-98

${ }^{+}$Corresponding author. Fax: +57-4-263.0935. E-mail: ppatino@catios.udea.edu.co

Received 8 April 2003

Accepted 11 February 2004 mal percentages of $\mathrm{CD} 3+, \mathrm{CD} 4+$, and $\mathrm{CD} 8+\mathrm{T}$ cells and IgE-bearing B lymphocytes (Buckley 2001); in addition, most patients have decreased or absent cutaneous reactivity (delayed hypersensitivity reactions, DTH) to candidin, tetanus toxoid (TT) or diphteria toxoid. In vitro studies of lymphocyte function generally reveal normal proliferation responses to Concanavalin A, Pokeweed mitogen, and Phytohemagglutinin A but low or absent T lymphocyte proliferation in response to specific antigens such as Candida albicans, TT, and Dermatophagoides pteronnysinus (Leung \& Geha 1988, Rodriguez et al. 1998, Buckley 2001). Reduced percentages of CD45RO+ memory T-cells in peripheral blood from HIES patients has been reported only once (Buckley et al. 1991), but the actual relevance of this finding or even the high $\operatorname{IgE}$ production in the patients' abnormal anamnesic humoral and cellular responses is presently unknown (Germain \& Stefanova 1999). Therefore, if HIES patients exhibit low or absent T cell proliferative responses to certain specific antigens, is possible that poor antigen-specific responses result from defective $\mathrm{T}$ cell activation or memory phenotype formation or a combination of both.

Activation of $\mathrm{T}$ lymphocytes requires the interaction between the T-cell antigen receptor (TCR)/CD3 complex with antigenic peptides presented by MHC-molecules expressed on antigen presenting cells (APCs). Additional signals come from the interactions of accessory molecules located on the cell surface of T-cell/APC synapses and of cytokines with their respective receptors. The molecules CD2, CD11a/CD18(LFA-1), CD28, CD45, CD152 (formerly CTLA-4), CD154 (formerly CD40L), ICOS, and 4-1BB are expressed on T-cells while CD40, CD54, CD80, CD86, and MAC-1 are expressed on the surface of APCs (reviewed in van Seventer et al. 1991, Germain \& Stefanova 1999, Singer \& Koretzky 2002). These molecules act by promoting adhesion, enhancing activation of TCR-mediated 
signals and providing costimulation to other cells during the immune response. These sequential interactions are in charge of sustaining, diversifying and amplifying the immune response (Bromley et al. 2001, Carreno \& Collins 2002). Several primary immunodeficiencies are the result of genetic defects that affect the expression and/or function of accessory molecules including X-linked hyper-IgM syndrome (HIGM1, OMIM \#308230) due to mutations in CD154 (Allen et al. 1993), and the leukocyte adhesion deficiency syndrome type I (LAD-1, OMIM \#116920), due to mutations in the in the CD18 gene (Marlin et al. 1986). Our group previously showed that HIES patients exhibit decreased expression of L-selectin in granulocytes and lymphocytes (Vargas et al. 1999); however, no studies have documented the expression and the role that the costimulatory molecules play in the activation of T cells in HIES.

The cytokines produced by activated $\mathrm{T}$ lymphocytes during an immune response promote their own differentiation and proliferation as well as the stimulation of other cells. Human T lymphocytes have heterogeneous profiles of cytokine production, but in CD4+ T cells at least two distinct subsets (Th1 and Th2) are recognized based on their production of well-defined cytokines. Th1 CD4+ cells produce mainly the cytokines interleukin 2 (IL-2) and interferon gamma (IFN- $\gamma$ ). IL-2 is a growth factor with autocrine and paracrine actions (Ballard 2001), while IFN- $\gamma$ is a promoter of the development and function of effector cells [phagocytes, natural killer cells (Aaltonen et al. 1997) and cytotoxic T lymphocytes (Boehm et al. 1997)]. Th2 CD4+ cells preferentially produce IL-4 promoting B-cell activation and isotype switch to IgE and IgG4 (Aversa et al. 1993, Banchereau et al. 1994). Studies involving the production and secretion of these cytokines and others such as IL-6, tumor necrosis factor (TNF), and IL-13 by antigen and mitogen-stimulated peripheral blood mononuclear cells (PBMCs) in HIES, have yielded conflicting results (Del Prete et al. 1989, Vercelli et al. 1990, Paganelli et al. 1991, Rodriguez et al. 1998, Garraud et al. 1999). Recently, two independent groups have shown additional alterations in the IFN- $\gamma /$ IL-12 pathways in HIES (Borges et al. 2000, Chehimi et al. 2001). Still, the cellular and molecular basis for the defects in IL-12 and IFN- $\gamma$ production as well as the $\mathrm{T}$ cell responsiveness to these cytokines in HIES remains speculative.

In the present study, using mixed leukocyte reactions (MLRs) as a model of T-cell activation we have evaluated the proliferative responses, the production of two cytokines and the expression of several accessory molecules in PBMCs from HIES patients and compared them with normal healthy controls. Our objective was to investigate possible alterations in the costimulatory activity during the interaction of T-cells and APCs in HIES.

\section{MATERIALS AND METHODS}

Subjects of the study - We evaluated six patients with clinical and laboratory diagnosis of HIES (4 males and 2 females; age ranges: 5 to 20 years) in agreement with established criteria (Group 1995, Grimbacher et al. 1999a). All patients had history of early onset chronic dermatitis, mucocutaneous candidiasis, skin abscesses, and suppurative pneumonias. Five patients developed persistent pneumatoceles that in four cases required surgery. Two patients had two or more fractures due to minimum trauma and in one patient, X-rays documented scoliosis. In addition, four out of six patients old enough for evaluation exhibited dental abnormalities and were reported previously (Otalvaro et al. 2001). Six healthy individuals paired by sex and ages were used as controls. An allogeneic pool was generated from three different healthy adults to stimulate T-cells from patients and controls. Clinical evaluation and medical examinations were performed with informed consent approved by the Ethical Committee from the Research Medical Center of the University of Antioquia.

Preparation of mononuclear cells - PBMCs from the patients, controls and those individuals selected for the allogeneic pool were isolated from heparinized venous blood by Ficoll-Hypaque (Sigma Chemical Co, St. Louis, MO). Half of the PBMCs were incubated with mytomicin $\mathrm{C}$ (Sigma) at a final concentration of $25 \mu \mathrm{g} / \mathrm{ml}$ for $30 \mathrm{~min} /$ $37^{\circ} \mathrm{C}$, washed in cold RPMI (Gibco-BRL Life Technologies, Gaithersburg, MD) at $250 \mathrm{~g} / 5 \mathrm{~min} / 4^{\circ} \mathrm{C}$, suspended in RPMI to a final concentration of $1 \times 10^{6}$ cells $/ \mathrm{ml}$, and used as stimulators (mytomicin C-treated PBMCs). The rest of the PBMCs were used as responder cells.

The mixed reactions used in all the experiments were established by culture of PBMCs in RPMI supplemented with 10\% human AB serum (Biowhittaker Inc., Walkersville, $\mathrm{MD}$ ) in a proportion 1:1 of responder to stimulator PBMCs, in three different combinations as follows: responder cells from each patient or control were cultured with their own mytomicin C-treated PBMCs (autologous reaction); responder cells from each patient were cultured with mytomicin C-treated PBMCs from a control and vice versa (single allogeneic reaction); and cells from each patient or control were cultured with a mixture of mytomicin C-treated PBMCs from three unrelated individuals (allogeneic pool reaction).

Cell proliferation assays - To evaluate cell proliferation $1 \times 10^{5} \mathrm{PBMCs} /$ well from each patient or control were cultured in RPMI supplemented with $10 \%$ human AB serum (complete RPMI) in 96 wells plates (Nunc, Naperville, IL) and stimulated with Phytohemaglutinin A (PHA) at the concentration of $10 \mu \mathrm{g} / \mathrm{ml}$ or alternatively, with $1 \times 10^{5}$ stimulator cells/well in the different combinations described. Cultures were incubated for three days (PHA) or six days (mixed reactions) at $37^{\circ} \mathrm{C}$ in $5 \% \mathrm{CO}_{2}$, and pulsed $18 \mathrm{~h}$ before harvesting with $1 \mu \mathrm{Ci} /$ well of thymidine $\left({ }^{3} \mathrm{H}-\right.$ thymidine, Amersham Inc, Piscataway, NJ). Finally, cells were harvested and the thymidine incorporation was measured in counts per minute using a scintillation counter (LKB, Turku, Finland).

Mixed reactions for quantification of cytokines PBMCs from patients or controls ( $1 \times 10^{6} /$ well) were resuspended in complete RPMI and cultured in 24 wells plates (Nunc) with mytomicin C-treated PBMCs $\left(1 \times 10^{6} \%\right.$ well) in the different combinations as described. The peaks of cytokines production in the mixed reactions were previously determined in healthy individuals (data not shown). Based in these results, IL-2 was measured after $72 \mathrm{~h}$ of culture, while IFN- $\gamma$ was measured at $120 \mathrm{~h}$. ELISA was used to quantitate the concentration of these cyto- 
kines in culture supernatants (Pharmingen, San Diego, CA).

Expression of accessory molecules by flow cytometry - PBMCs from patients and controls were cultured in autologous and allogeneic reactions as previously described, and cells were incubated with fluorochrome-labeled mouse monoclonal antibodies directed against the human molecules CD28, CD80, CD86, CD40, CD154, CD54, and CD11a (all from Pharmingen). Briefly, cells were washed in $1 \mathrm{ml}$ of PBS pH 7.4 supplemented with $1 \%$ fetal bovine serum and $0.1 \%$ sodium azide (cytometry buffer) at $250 \mathrm{~g} / 6 \mathrm{~min} / \mathrm{RT}$, resuspended in $300 \mu \mathrm{l}$ of this buffer and stained with monoclonal antibodies for $20 \mathrm{~min} / 4^{\circ} \mathrm{C}$ in the dark. Finally, cells were washed twice with cytometry buffer and fixed in PBS pH 7.2, $1 \%$ paraformaldehyde, $0.1 \%$ sodium azide and analyzed in a Coulter Epics XL flow cytometer equipped with a $488 \mathrm{~nm}$-argon laser (Beckman Coulter, Miami, FL). Maximum expression of accessory molecules in the mixed cultures was previously determined in healthy individuals and based on these results we measured CD28, CD80, CD40, and CD11a after $24 \mathrm{~h}$ of culture, while CD86, CD154, and CD54 were measured after $72 \mathrm{~h}$.

Statistical analysis - Arithmetic means and standard errors were obtained for each experiment, and the statistical significance determined with the t student test comparing two independent groups; one-way ANOVA test was used to compare more than two non-paired groups. All the significant values were evaluated using the Kolmogorov-Smirnov test of normality. The statistical analyses were done with the Graph Pad Prism V.2 (Graph Pad Software, San Diego, CA).

\section{RESULTS}

Proliferative responses in HIES patients and controls in cultures after mitogenic and allogeneic stimulation To determine the proliferative responses to mitogen and allogeneic stimuli, PBMCs from HIES patients and controls were cultured with PHA or autologous, allogeneic cells and an allogeneic pool of PBMCs as described. As shown in Table I, proliferation of PBMCs in mixed cultures was similar between HIES patients and controls regardless of the stimuli used (PHA, autologous, single allogeneic, and allogeneic pool). Both single and multi allogeneic stimulation induced proliferation in the two groups, while the autologous stimuli did not induce measurable levels of proliferation as expected.
Secretion of cytokines by PBMCs from HIES patients stimulated with allogeneic PBMCs - Production of several cytokines including IL-2, IFN- $\gamma$, IL-4, and others in supernatants from mitogen-stimulated cells from HIES patients has been addressed extensively with heterogeneous results (Del Prete et al. 1989, Vercelli et al. 1990, Paganelli et al. 1991, Rousset et al. 1991, Rodriguez et al. 1998, Garraud et al. 1999, Ohga et al. 2003); yet no experimental evidence is available with respect to differences in cytokine production in HIES when T cells are activated using allogeneic stimulus. Therefore we evaluated the production of the cytokines IL-2 and IFN- $\gamma$ in supernatants derived from PBMCs of HIES and controls using mytomicin-treated allogeneic PBMCs. As shown in Table II, the allogeneic stimulation (particularly the stimulation with the allogeneic pool of PBMCs) produced significant increases in the production of IL-2 and IFN- $\gamma$ in culture supernatants and these differences were statistically significant when compared with that of the autologous stimulation. However, regardless of the conditions used for the stimulation of the PBMCs in culture, the concentrations of IL- 2 and IFN- $\gamma$ in the supernatants were not significantly different between HIES patients and controls.

Modulation of the expression of accessory molecules in PBMCs stimulated with allogeneic cells - Abnormalities in the expression of accessory molecules has not been previously documented in association with decreased $\mathrm{T}$ cell activation in HIES. Therefore, to investigate possible abnormalities in the expression and/or induction of some of these molecules, PBMCs from patients and controls were cultured with autologous and allogeneic stimuli as described, and the expression of several accessory molecules was measured by flow cytometry. As shown in Figs 1 and 2, expression of CD11a, CD28, CD40, CD80, CD86, and CD154 in PBMCs was not statistically different between patients and controls, regardless of the stimuli used. Interestingly, the level of expression of most of these molecules for both groups was similar after the autologous and allogeneic stimuli, and only minor increases in the expression (as in the expression of CD80 and CD86) or decreases (as in the expression of CD154), were observed and these results contrast with the significant differences observed in proliferation and cytokine production in response to the same stimuli. The only major difference observed between HIES patients and controls with respect to accessory molecules was in the expression of

TABLE I

Peripheral blood mononuclear cells proliferation in cultures from hyper-IgE syndrome patients and healthy controls

\begin{tabular}{lccc}
\hline & $\begin{array}{c}\text { Controls } \\
\mathrm{N}=6\end{array}$ & $\begin{array}{c}\text { Patients } \\
\mathrm{N}=6\end{array}$ & $p$ values \\
Sean ${ }^{a} \pm \mathrm{SE}$ & $945 \pm 128$ & $1278 \pm 265$ & 0.2842 \\
Stimulus in culture & $39893 \pm 8187$ & $34092 \pm 9863$ & 0.6605 \\
Unstimulated & $1678 \pm 290$ & $1215 \pm 134$ & 0.1788 \\
Phytohemaglutinin & $10858 \pm 2132$ & $15866 \pm 5436$ & 0.4111 \\
Autologous & $24754 \pm 2864$ & $20309 \pm 6471$ & 0.1787 \\
Single allogeneic & Allogeneic pool & &
\end{tabular}

$a$ : counts per minute; SE: standard error; $p$ : difference between patients and controls 
TABLE II

Cytokine concentrations in supernatants from peripheral blood mononuclear cells mixed cultures from hyper-IgE syndrome patients and healthy controls

\begin{tabular}{|c|c|c|c|c|}
\hline Cytokine & Stimulus & $\begin{array}{c}\text { Controls } \\
\mathrm{N}=6 \\
\text { Mean }^{a} \pm \mathrm{SE}\end{array}$ & $\begin{array}{c}\text { Patients } \\
\mathrm{N}=6 \\
\text { Mean }^{a} \pm \mathrm{SE}\end{array}$ & $p$ values $b$ \\
\hline Interleukin-2 & $\begin{array}{l}\text { Autologous } \\
\text { Single allogeneic } \\
\text { Allogeneic pool } \\
p \text { values }{ }^{c}\end{array}$ & $\begin{array}{c}17 \pm 4 \\
308 \pm 77 \\
494 \pm 75 \\
0.0003\end{array}$ & $\begin{array}{c}14 \pm 3 \\
292 \pm 85 \\
499 \pm 74 \\
0.0004\end{array}$ & $\begin{array}{l}0.6006 \\
0.8918 \\
0.9652\end{array}$ \\
\hline IFN gamma & $\begin{array}{l}\text { Autologous } \\
\text { Single allogeneic } \\
\text { Allogeneic pool } \\
p \text { values }{ }^{c}\end{array}$ & $\begin{array}{c}56 \pm 17 \\
399 \pm 93 \\
683 \pm 103 \\
0.0003\end{array}$ & $\begin{array}{c}41 \pm 13 \\
547 \pm 126 \\
839 \pm 172 \\
0.0013\end{array}$ & $\begin{array}{l}0.5050 \\
0.3652 \\
0.4570\end{array}$ \\
\hline
\end{tabular}

$a$ : cytokine values in $\mathrm{pg} / \mathrm{ml} ; b: p$ : difference between patients and controls; $c$ : $p$ : difference between stimuli, obtained using one-way ANOVA test; SE: standard error
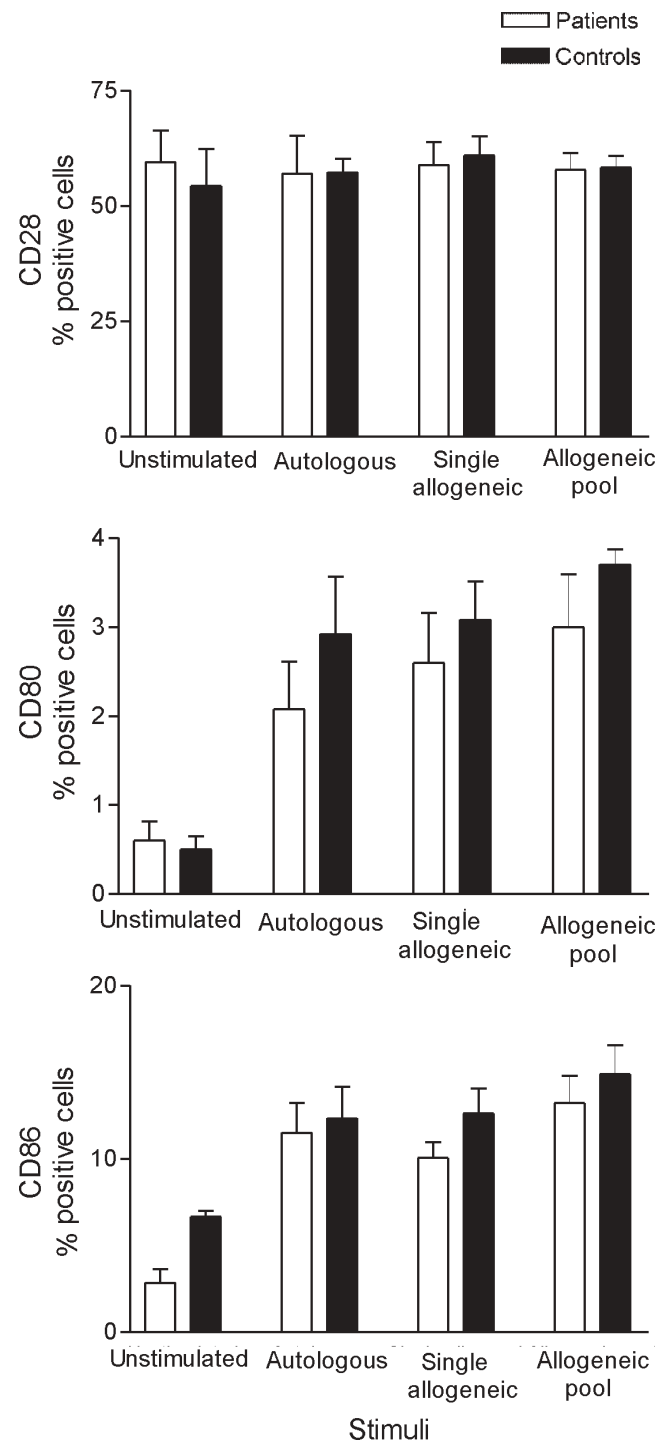

Fig. 1: expression of accessory molecules CD28, CD80, and CD86 by flow cytometry (expressed as percentage of positive cells) in mixed cultures of peripheral blood mononuclear cells from hyperIgE syndrome patients and healthy controls. The bars represent the average of six independent experiments.
CD54. HIES patients showed significant less expression after autologous and allogeneic stimuli (Fig. 2); of interest was that the allogeneic stimulus induced some expression of CD54 as compared with the autologous stimulus, but it never reached the levels obtained in the controls.

\section{DISCUSSION}

We have shown here that proliferative responses of PBMCs to alloantigens or PHA were similar in HIES patients and healthy controls, in agreement with previous results showing that PBMCs from HIES patients when stimulated with non-related allogeneic mononuclear cells, proliferate normally (Buckley \& Samson 1981). However, decreases in lymphoid proliferative responses in vitro after the challenge with specific antigens such as tetanus toxoid and candidin, is also consistently observed in most HIES patients (Buckley \& Samson 1981, Geha \& Leung 1989). These results are not unexpected since both allogeneic and mitogen stimuli give rise to strong $\mathrm{T}$ cell proliferation, due mainly to higher number of $\mathrm{T}$ cell clones that can be activated through this process, rather than those that are activated with conventional antigens.

Using a model of mixed lymphocyte reactions we did not find abnormalities in IL- 2 and IFN- $\gamma$ secretion by PBMCs from HIES patients, in agreement with other recent studies showing no significant differences in the secretion of these two cytokines in HIES (Rodriguez et al. 1998, Chehimi et al. 2001). This data particularly with respect to IFN- $\gamma$, contrasts with results published by others showing that mononuclear cells from HIES patients produce lower quantities of IFN- $\gamma$ than healthy controls (Del Prete et al. 1989, Paganelli et al. 1991, Garraud et al. 1999). An explanation to this apparent discrepancy in cytokine production could be the types of stimuli used and their capacity to activate different lymphoid clones. Lower secretion of IFN- $\gamma$ was reported when PBMCs were cultured with Staphylococcus aureus, which has conventional memory antigens that activate fewer T-cell clones (Garraud et al. 1999), suggesting that in HIES all lymphocytes are not disabled to secrete IFN- $\gamma$. Differential functional activity of lymphocyte subpopulations has also 
been observed depending on the type of stimuli used; particularly, Via and collaborators (1990) observed that in healthy individuals, IL-2 production and proliferative responses to conventional antigens such as influenza or tetanus depended exclusively on the presence of CD4+
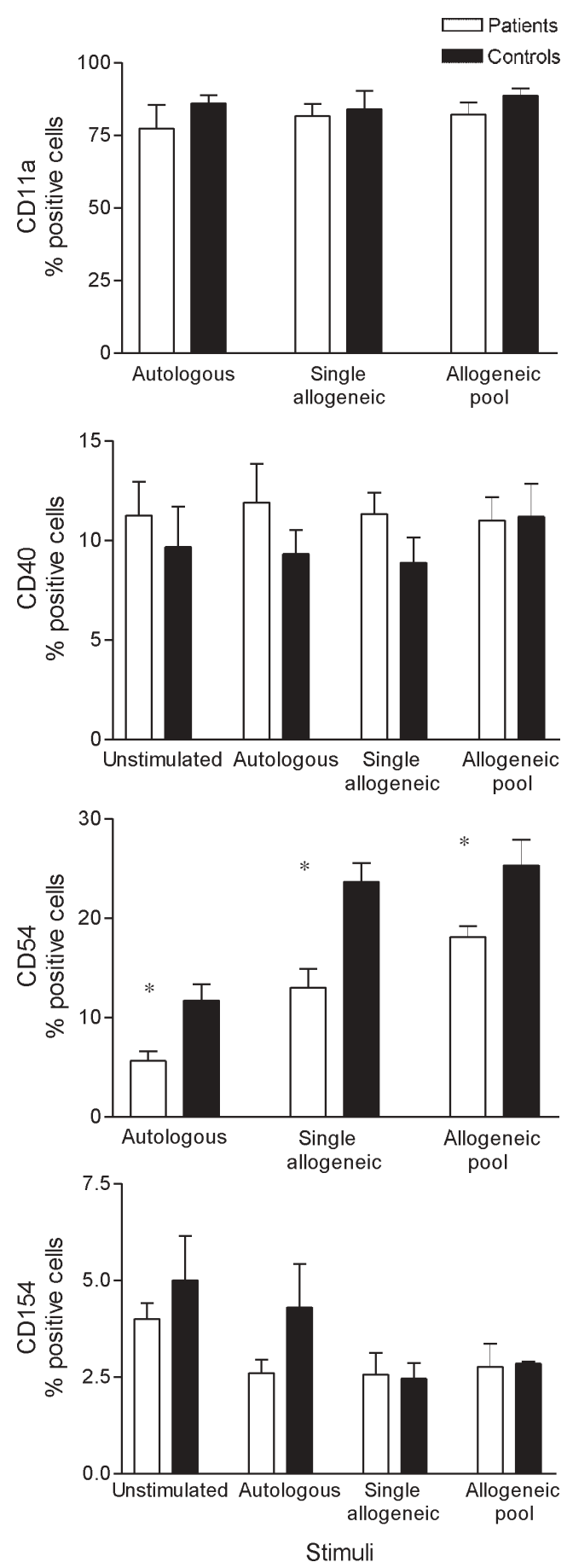

Fig. 2: expression of accessory molecules CD11a, CD40, CD54, and CD154 by flow cytometry (expressed as percentage of positive cells) in mixed cultures of peripheral blood mononuclear cells from hyper-IgE syndrome patients and healthy controls. The bars represent the average of six independent experiments. For CD54, the $p$ values were obtained by one-way ANOVA and indicate the comparison among healthy controls and HIES patients; $* p<0.05$
T-cells, while CD4+, and CD8+ T-cells mediated proliferation and IL-2 secretion in response to alloantigens.

To date no studies have documented the expression of costimulatory molecules in response to autologous and allogeneic stimuli in HIES. We investigated the expression of CD11a, CD28, CD40, CD54, CD80, CD86, and CD154, after primary autologous and MLRs in 6 HIES patients and controls and found no major differences in the expression of most accessory molecules, with the exception of CD54. CD54 or intercellular adhesion molecule 1 (ICAM-1) is an inducible cell adhesion transmembrane glycoprotein of the immunoglobulin supergene family, that is present constitutively on the cell surface of a wide variety of cell types including fibroblasts, leukocytes, keratinocytes, endothelial cells, and is upregulated in response to a number of inflammatory mediators (reviewed in Roebuck \& Finnegan 1999). It contains extracellular immunoglobulin-like domains that function in cell-cell and cell-matrix adhesive interactions, through the binding to two other integrins belonging to the $\beta 2$ subfamily (CD11a/ CD18 and CD11b/CD18) (van de Stolpe \& van der Saag 1996). These adhesive interactions are critical for the transendothelial migration of leukocytes and the activation of $\mathrm{T}$ cells where CD54 binding functions as a coactivation signal (Van Seventer et al. 1990, Dubey et al. 1995, Zuckerman et al. 1998). Deficient mice exhibit prominent abnormalities in inflammatory responses including impaired neutrophil emigration to the peritoneum and decreased contact hypersensitivity to different chemicals (Sligh et al. 1993). In addition, host defenses against disseminated Candida albicans infections are impaired in ICAM-1-deficient mice (Davis et al. 1996). Furthermore, low serum concentrations of CD54 have been recently associated with early onset infections caused by different species of Candida in a population of patients belonging to a single family (Zuccarello et al. 2002). Mucocutaneous candidiasis is a common clinical finding that often accompanies HIES and is diagnosed in up to $80 \%$ of the patients as shown in the largest cohorts published to date (Grimbacher et al. 1999a, 2002). Because CD54 seems to be critical for the immune response against certain forms of Candida infections, we believe that defective expression of CD54 as well, could be partly responsible for the increased incidence of at least this form of infection in HIES.

ICAM-1 expression can be detected on approximately $40 \%$ of the resting peripheral blood T cells and cytokines like IL-2 and IFN- $\gamma$ are able to increase its expression (Buckle \& Hogg 1990). In addition, pretreatment of human $\mathrm{T}$ cells with an anti-ICAM-1 monoclonal antibody inhibits their response to recall antigens, strongly suggesting a functional role for this protein on memory $\mathrm{T}$ cells. Furthermore, addition of anti-ICAM-1 mAb caused inhibition of homotypic aggregation of human $\mathrm{B}$ cells in vitro, but augmented IgE synthesis when cells where stimulated with anti-CD40 mAb and IL-4 (Katada et al. 1996). Our findings will be extended to other in vitro culture systems to address in more detail the role that CD54 plays in $\mathrm{T}$ and $\mathrm{B}$ cell costimulation and IgE regulation in HIES.

Past and present efforts aimed to reveal abnormalities in complex immunological networks in primary immuno- 
deficiencies, has resulted in a more profound understanding of the role of these molecules in the regulation of immune responses in normal individuals; however, they have not broadened substantially our understanding of the role they play in HIES. HIES is certainly heterogeneous and the recognition of its wide spectrum of phenotypes that lead to multiple clinical manifestations is critical to understanding the pathogenic mechanisms underlying this disease. The study of the role that accessory molecules and cytokines play in the pathogenesis of the disease should complement efforts towards the identification of the genetic defect.

\section{ACKNOWLEDGEMENTS}

To Fabiola Toro and Liliana Arango for their invaluable collaboration in the flow cytometry analysis of the samples.

\section{REFERENCES}

Aaltonen J, Björses P, Perheentupa J, Kuitunen N, Palotie A, Peltonen L, Su Lee Y, Francis F, Hennig S, Thiel C, Lehrach H, Yaspo M 1997. An autoimmune disease, APECED, caused by mutations in a novel gene featuring two PHDtype zinc-finger domains. The Finnish-German APECED Consortium. Autoimmune Polyendocrinopathy-Candidiasis-Ectodermal Dystrophy. Nat Genet 17: 399-403.

Allen RC, Armitage RJ, Conley ME, Rosenblatt H, Jenkins NA, Copeland NG, Bedell MA, Edelhoff S, Disteche CM, Simoneaux DK, Fanslow WC, Belmont J, Spriggs MK 1993. CD40 ligand gene defects responsible for X-linked hyperIgM syndrome. Science 259: 990-993.

Aversa G, Punnonen J, Cocks BG, de Waal Malefyt R, Vega F Jr, Zurawski SM, Zurawski G, Vries JE 1993. An interleukin 4 (IL-4) mutant protein inhibits both IL-4 or IL-13- induced human immunoglobulin G4 (IgG4) and IgE synthesis and B cell proliferation: support for a common component shared by IL-4 and IL-13 receptors. J Exp Med 178: 22132218.

Ballard DW 2001. Molecular mechanisms in lymphocyte activation and growth. Immunol Res 23: 157-166.

Banchereau J, Briere F, Galizzi JP, Miossec P, Rousset F 1994. Human interleukin 4. J Lipid Mediat Cell Signal 9: 43-53.

Boehm U, Klamp T, Groot M, Howard JC 1997. Cellular responses to interferon-gamma. Annu Rev Immunol 15: 749-795.

Borges WG, Augustine NH, Hill HR 2000. Defective interleukin12/interferon-gamma pathway in patients with hyperimmunoglobulinemia E syndrome. J Pediatr 136: 176-180.

Bromley SK, Burack WR, Johnson KG, Somersalo K, Sims TN, Sumen C, Davis MM, Shaw AS, Allen PM, Dustin ML 2001. The immunological synapse. Annu Rev Immunol 19: 375-396.

Buckle AM, Hogg N 1990. Human memory T cells express intercellular adhesion molecule- 1 which can be increased by interleukin 2 and interferon-gamma. Eur J Immunol 20: 337341.

Buckley RH 2001. The hyper-IgE syndrome. Clin Rev Allergy Immunol 20: 139-154.

Buckley RH, Samson HA 1981. The hyperimmunoglobulinemia E syndrome. In EC Franklin, Clinical Immunology Update: Reviews for Physicians, Elsevier North-Holland, New York, p. $147-167$.

Buckley RH, Schiff S, Hayward A 1991. Reduced frequency of $\mathrm{CD} 45 \mathrm{RO}+\mathrm{T}$ lymphocytes in blood of hyper IgE syndrome patients. J Allergy Clin Immunol 87: 309.

Carreno BM, Collins M 2002. The B7 family of ligands and its receptors: new pathways for costimulation and inhibition of immune responses. Annu Rev Immunol 20: 29-53.

Chehimi J, Elder M, Greene J, Noroski L, Stiehm ER, Winkelstein JA, Sullivan KE 2001. Cytokine and chemokine dysregulation in hyper-IgE syndrome. Clin Immunol 100: 49-56.

Davis SL, Hawkins EP, Mason EO Jr, Smith CW, Kaplan SL 1996. Host defenses against disseminated candidiasis are impaired in intercellular adhesion molecule 1-deficient mice. J Infect Dis 174: 435-439.

Del Prete G, Tiri A, Maggi E, De Carli M, Macchia D, Parronchi P, Rossi ME, Pietrogrande MC, Ricci M, Romagnani S 1989. Defective in vitro production of gamma-interferon and tumor necrosis factor-alpha by circulating $\mathrm{T}$ cells from patients with the hyper- immunoglobulin E syndrome. $J$ Clin Invest 84: 1830-1835.

Dubey C, Croft M, Swain SL 1995. Costimulatory requirements of naive CD4+ T cells. ICAM-1 or B7-1 can costimulate naive CD4 $\mathrm{T}$ cell activation but both are required for optimum response. J Immunol 155: 45-57.

Garraud O, Mollis SN, Holland SM, Sneller MC, Malech HL, Gallin JI, Nutman TB 1999. Regulation of immunoglobulin production in hyper-IgE (Job's) syndrome. J Allergy Clin Immunol 103: 333-340.

Geha RS, Leung DY 1989. Hyper immunoglobulin E syndrome. Immunodefic Rev 1: 155-172.

Germain RN, Stefanova I 1999. The dynamics of T cell receptor signaling: complex orchestration and the key roles of tempo and cooperation. Annu Rev Immunol 17: 467-522.

Grimbacher B, Holland SM, Gallin JI, Greenberg F, Hill SC, Malech HL, Miller JA, O-Connell AC, Puck JM 1999a. Hyper-IgE syndrome with recurrent infections - An autosomal dominant multisystem disorder. $N$ Engl J Med 340: 692-702.

Grimbacher B, Holland S, Renner E, Franco J, Pietrogrande C, Schmittel A, Erlewynl-Lajeunesse M, Sanchez B, Pereira L, Davis J, Schnopp N, Weiss N, Abeck D, Belohradsky B, Puck J 2002. Diagnosing the hyper-IgE syndrome: incidence of clinical features. Inmunologia 21: 2-4.

Grimbacher B, Schaffer AA, Holland SM, Davis J, Gallin JI, Malech HL, Atkinson TP, Belohradsky BH, Buckley RH, Cossu F, Espanol T, Garty BZ, Matamoros N, Myers LA, Nelson RP, Ochs HD, Renner ED, Wellinghausen N, Puck JM 1999b. Genetic linkage of hyper-IgE syndrome to chromosome 4. Am J Hum Genet 65: 735-744.

Group WHO scientific committee 1995. Primary immunodeficiency diseases: report of a WHO scientific group. Clin Exp Immunol 99: 1-24.

Katada Y, Tanaka T, Ochi H, Aitani M, Yokota A, Kikutani H, Suemura M, Kishimoto T 1996. B cell-B cell interaction through intercellular adhesion molecule-1 and lymphocyte functional antigen-1 regulates immunoglobulin E synthesis by B cells stimulated with interleukin- 4 and anti-CD40 antibody. Eur J Immunol 26: 192-200.

Leung DY, Geha RS 1988. Clinical and immunologic aspects of the hyperimmunoglobulin E syndrome. Hematol Oncol Clin North Am 2: 81-100.

Marlin SD, Morton CC, Anderson DC, Springer TA 1986. LFA1 immunodeficiency disease. Definition of the genetic defect and chromosomal mapping of alpha and beta subunits of the lymphocyte function-associated antigen 1 (LFA-1) by complementation in hybrid cells. J Exp Med 164: 855867.

Ohga S, Nomura A, Ihara K, Takahata Y, Suga N, Akeda H, Shibata R, Okamura J, Kinukawa N, Hara T 2003. Cytokine imbalance in hyper-IgE syndrome: reduced expression of 
transforming growth factor beta and interferon gamma genes in circulating activated T cells. Br J Haematol 121: 324331.

Otálvaro N, Montoya CJ, Espinal G, López GE, Becerra F, Cadavid RH, Patiño PJ, Restrepo DP 2001. Caracterización clínico odontológica de las alteraciones en el sistema estomatológico de los pacientes con síndrome de hiperinmunoglobulinemia E con infección recurrente (SHIEIR). Avances en Odontoestomatología 17:313-323.

Paganelli R, Scala E, Capobianchi MR, Fanales-Belasio E, D'Offizi G, Fiorilli M, Aiuti F 1991. Selective deficiency of interferon-gamma production in the hyper-IgE syndrome. Relationship to in vitro IgE synthesis. Clin Exp Immunol 84: 28-33.

Renner E, Puck J, Holland S, Schmitt M, Weiss M, Frosch M, Bergmann M, Davis J, Belohradsky B, Grimbacher B 2002. The autosomal recessive hyper-IgE syndrome in six consanguineous kindreds presents a distinct disease entity. Clin Immunol 103: S115.

Rodriguez MF, Patino PJ, Montoya F, Montoya CJ, Sorensen RU, Garcia de Olarte D 1998. Interleukin 4 and interferongamma secretion by antigen and mitogen-stimulated mononuclear cells in the hyper-IgE syndrome: no TH-2 cytokine pattern. Ann Allergy Asthma Immunol 81: 443-447.

Roebuck KA, Finnegan A 1999. Regulation of intercellular adhesion molecule-1 (CD54) gene expression. J Leukoc Biol 66: 876-888.

Rousset F, Robert J, Andary M, Bonnin JP, Souillet G, Chretien I, Briere F, Pene J, de Vries JE. 1991. Shifts in interleukin4 and interferon-gamma production by $\mathrm{T}$ cells of patients with elevated serum IgE levels and the modulatory effects of these lymphokines on spontaneous IgE synthesis. $\mathrm{J} \mathrm{Al}$ lergy Clin Immunol 87: 58-69.

Singer AL, Koretzky GA 2002. Control of T cell function by positive and negative regulators. Science 296: 1639-1640.
Sligh Jr JE, Ballantyne CM, Rich SS, Hawkins HK, Smith CW, Bradley A, Beaudet AL 1993. Inflammatory and immune responses are impaired in mice deficient in intercellular adhesion molecule 1. Proc Natl Acad Sci USA 90: 8529-8533.

van de Stolpe A, van der Saag PT 1996. Intercellular adhesion molecule-1. J Mol Med 74: 13-33.

van Seventer GA, Shimizu Y, Horgan KJ, Shaw S 1990. The LFA-1 ligand ICAM-1 provides an important costimulatory signal for $\mathrm{T}$ cell receptor-mediated activation of resting $\mathrm{T}$ cells. J Immunol 144: 4579-4586.

van Seventer GA, Shimizu Y, Shaw S 1991. Roles of multiple accessory molecules in T-cell activation. Curr Opin Immunol 3: 294-303.

Vargas L, Patino PJ, Rodriguez MF, Forero C, Montoya F, Montoya CJ, Sorensen RU, Garcia de Olarte D 1999. Increase in granulocyte-macrophage-colony-stimulating factor secretion and the respiratory burst with decreased Lselectin expression in hyper-IgE syndrome patients. Ann Allergy Asthma Immunol 83: 245-251.

Vercelli D, Jabara HH, Cunningham-Rundles C, Abrams JS, Lewis DB, Meyer J, Schneider LC, Leung DY, Geha RS 1990. Regulation of immunoglobulin (Ig)E synthesis in the hyper-IgE syndrome. J Clin Invest 85: 1666-1671.

Via CS, Tsokos GC, Stocks NI, Clerici M, Shearer GM 1990. Human in vitro allogeneic responses. Demonstration of three pathways of T helper cell activation. J Immunol 144: 25242528.

Zuccarello D, Salpietro DC, Gangemi S, Toscano V, Merlino MV, Briuglia S, Bisignano G, Mangino M, Mingarelli R, Dallapiccola B 2002. Familial chronic nail candidiasis with ICAM-1 deficiency: a new form of chronic mucocutaneous candidiasis. J Med Genet 39: 671-675.

Zuckerman LA, Pullen L, Miller J 1998. Functional consequences of costimulation by ICAM-1 on IL- 2 gene expression and T cell activation. J Immunol 160: 3259-3268. 